Diş aşınmalarının sınıflandırılması ve teşhiste kullanılan indeksler

\section{Classification of tooth wear and indexes used in diagnosis}

\author{
Dr. Öğr. Üyesi Sezgi Cinel Şahin \\ Pamukkale Üniversitesi, Diş Hekimliği Fakültesi, Pro- \\ tetik Diş Tedavisi A.D., Denizli
}

Orcid ID: 0000-0001-7623-782X

\section{Arş. Gör. Dt. Çağrı Koyal}

Pamukkale Üniversitesi, Diş Hekimliği Fakültesi, Protetik Diş Tedavisi A.D., Denizli

Orcid ID: 0000-0002-3500-4031

Geliş tarihi: 26 Mayıs 2020

Kabul tarihi: 9 Ekim 2020

doi: 10.5505/yeditepe.2021.71602

\section{Yazışma adresi:}

Sezgi Cinel Şahin

Pamukkale Üniversitesi Diş Hekimliği Fakültesi Protetik Diş Tedavisi A.D., Kınıklı Kampüs

Çamlaraltı Mahallesi, Süleyman Demirel Cad. No:95,

Posta kodu:20160 Pamukkale/Denizli

Tel: +905058996237

Fax: +902582961763

E-posta: sezgis@pau.edu.tr

Fax: +902125310515

E-posta: tugceceloglu@hotmail.com
ÖZET

Çürüksüz diş yüzey kayıpları olarak tanımlanan atrizyon, abrazyon, erozyon ve abfraksiyon lezyonları etiyolojileri farklı olsa da temelde diş yapılarında değişiklikle kendilerini gösterir ve "diş aşınmaları" olarak nitelendirilir. Diş aşınmaları klinisyenler için ciddi bir problem oluşturmaktadır. Ancak özellikle terminolojideki farklııklar ve diş sert doku kaybının teşhisinde, sınıflandırımasında ve takibinde kullanılabilecek çok sayıda indeksin varlığı nedeniyle literatürdeki klinik ve epidemiyolojik çalışmaların yorumlanması oldukça zordur. Bu derlemenin amacı, diş aşınmalarını etiyolojilerine göre sınıflandırarak, günümüze kadar kullanılan değerlendirme indekslerinin evrimini analiz etmek ve bu indekslerin diş hekimliğindeki klinik ihtiyaçları karşılayıp karşılamadıklarını değerlendirmektir.

Anahtar kelimeler: Atrizyon, abrazyon, erozyon, abfraksiyon, diş aşınması

\section{SUMMARY}

Despite the different etiologies of attrition, abrasion, erosion and abfraction lesions, which are defined as caries-free tooth surface losses, they are mainly manifested by changes in tooth structures and are considered to be "tooth wear". Tooth wear is a serious problem for clinicians. However, clinical and epidemiological studies in the literature are very difficult to interpret, especially due to differences in terminology and the presence of a large number of indices that can be used in the diagnosis, classification and follow-up of tooth hard tissue loss. The purpose of this review is to classify the tooth wear according to their etiology, to analyze the evolution of the evaluation indices used to date, and to evaluate whether they meet clinical needs in dentistry.

Keywords: Abrasion, attrition, abfraction, erosion, tooth wear Giriș

"Diş aşınması" olarak adlandırılan çürüksüz diş yüzey kayıpları, ${ }^{1,2}$ diş sert dokusunun geri dönüşümsüz şekilde kaybedilmesini ifade etmektedir. ${ }^{3}$ Diş aşınmaları, fizyolojik veya patolojik nedenlerle ortaya çıkabilir. Fizyolojik aşınmalar, çiğneme fonksiyonu ve yaşlanma sürecinin bir sonucu olarak ortaya çıkan, ${ }^{2,4,5}$ yılda yaklaşık 28-30 $\boldsymbol{\mu}$ n'lik mine kaybına neden olan bir süreçtir. ${ }^{6}$ Fizyolojik diş aşınması, komşu dişler arasındaki sürtünme nedeniyle, proksimal diş yüzeylerinde de ortaya çıkabilir. ${ }^{5,7}$ Diş aşınmasının seviyesi diş vitalitesini tehlikeye attığında veya mevcut yaşla orantısız olduğunda ise patolojik olarak adlandırıır. ${ }^{6,8}$

Diş aşınmalarının erken evrede teşhis edilmesi, etiyolojisinin tanımlanması ve gereken önleyici tedbirlerin alınması oldukça önemlidir. Bu amaçla diş hekimleri, aşınmanın nedenlerinin yanı sıra, aşınmanın şiddetinde ve ilerlemesinde rol oynayan faktörleri de mutlaka ayrıntılı bir şekilde araştırmalıdır.9,10 Aşınmanın etiyolojisinde diyetin tipi, bruksizm ve diğer parafonksiyonel aktivitelerin varlığı gibi çok sayıda faktör bulunurken, travma, bakteriyel etkenler veya gelişimsel bozuklukların ise etiyolojide yeri olmadığı bilinmektedir.,10 
Etiyolojisinin multifaktöriyel ve komplike olmasının yanı sıra günümüze kadar kullanılan değerlendirme kriterlerindeki farklııklar nedeniyle, diş aşınmalarının kesin prevalansını belirlemek oldukça zordur.11 Bu konuda yapılan tüm çalışmalar, beklenildiği gibi yaşla birlikte prevalansta bir artış olduğunu göstermiştir.6,12,13

\section{Diş AŞINMALARININ SINIFLANDIRILMASI}

Diş aşınmasılarına sebep olan etkenler belirlenirken ve tedavi planı formüle edilirken, aşınmanın doğası dikkate alınmalıdır. ${ }^{9,14,15}$ Bu düşünceyle, 1991 yılında Grippo, dişlerin sert doku kayıplarına ait bir sınıflama ortaya koymuş ve buna göre, farklı nedenlerle ortaya çıkan dört tip sert doku kaybını tanımlanmıştır. Bu tanımlamaya göre diş sert doku kayıpları, atrizyon, abrazyon, abfraksiyon veya erozyon (biyo-korozyon) olarak dört sınıfta incelenmektedir. ${ }^{16}$

\section{ATRIZYON}

Atrizyon, karşılıklı dişlerin teması nedeniyle diş dokusunun veya restorasyonun aşınması olarak tanımlanır ve atrizyonun genellikle parafonksiyonel aktivite ile ilişkili olduğu düşünülmektedir.,13,17-21

Atrizyon kaynaklı aşınmalar, posterior dişlerin oklüzal yüzeylerinde, maksiller anterior dişlerin palatinal, mandibular anterior dişlerin ise labial yüzeylerinde ve anterior dişlerin insizal kenarlarında lokalize olabilir. Etkilenen yüzeyler genellikle sert, pürüzsüz ve parlaktır. Aşınma mineye nüfuz etmişse, atrizyon alanları sarımsı kahverengi bir renk değişikliği gösterebilir. Atrizyona neden olan faktör halen aktif ise, diş aşınma alanları genellikle parlak ve iyi sınırlı çukurlar şeklinde görülür. ${ }^{5}$ Posterior diş eksikliğinin protetik olarak tedavi edilmemesi dolayısıyla oluşan oklüzal düzensizliklerin de atrizyon oluşumuna yatkınlığı arttırdığı düşünülmektedir. ${ }^{19}$

\section{ABRAZYON}

Diş yüzeyi ve karşıt diş dışındaki diğer etkenler nedeniyle oluşan sürtünme sonucunda diş yüzeylerinde meydana gelen aşınma olarak tanımlanır. ${ }^{18,21,22}$ Abrazyonun ortaya çıkışında genellikle hastalarla ilgili faktörler etkilidir ve özellikle diş fırçalama şeklinin abrazyonun ana etiyolojik faktörü olduğu kabul edilir. 23,24

Pürüzsüz yüzeylerin ve/veya servikal abrazyonların tespit edildiği hastalar genellikle klinik olarak iyi bir ağız hijyenine sahiptir. Bu tip hastalarda, şiddetli fırçalama tekniğine, fırçalamaya harcanan zamana ve fırçalama sırasında uygulanan kuvvete bağlı olarak servikal abrazyonlar görülebilmektedir. ${ }^{25}$ Abrazyona sebep olan diğer dış faktörler ise şunlardır:

a) Materyal kaynaklı faktörler: Fırçalama için kullanılan diş macunlarının miktarı, macunun $\mathrm{pH}^{\prime} ı$ ve aşındırıcılığının da abrazyon sebebi olabileceği bulunmuştur. Benzer şekilde, fırçanın sertliği/esnekliği ve kıl tasarımının da özellikle agresif fırçalama teknikleriyle ilişkilendirildiklerinde abrazyon prevalansının artmasına neden olabileceği görülmüştür. ${ }^{24-27}$ Restoratif tedaviler açısından düşünül- düğünde ise, uygun şekilde cilalanmamış porselen restorasyonlar da karşıt doğal dişlerin abrazyonuna neden olabilecek faktörler arasındadır. ${ }^{28}$

b) Çevresel faktörler: Bu faktörler arasında, sürekli olarak toza ve kuma maruz kalınması ve yeterli şekilde yıkanmamış olması nedeniyle hala eser miktarda toprak içeren sebzelerin tüketimi sayılabilir. ${ }^{29,30}$

Abrazyonun gelişiminde bu faktörlerin yanı sıra, erozyon ve abfraksiyon gibi diğer kofaktörler de rol oynayabilmektedir. Bu nedenle abrazyona neden olan etiyolojik faktörün tespitinde kesin bir hükme varılması zordur.7,17,27,31,32 Klinik olarak servikal abrazyon genellikle, bir veya daha fazla dişin fasial yüzeyinde oluşan " $V$ " şeklinde çentikler şeklinde karşımıza çıkar. ${ }^{33}$ Keskin sınırlı kenarlar ve pürüzsüz yüzeyler ile karakterizedir.,27 Ancak abrazyonlar sadece servikal bölgelerde değil, interdental fırçaların veya diş iplerinin agresif kullanımı sonucunda interdental alanlarda da gözlemlenebilir. ${ }^{25}$ Ayrıca pipo içimi, fındık ve çekirdeklerin dişlerle ayıklanması, çivi veya iplik ısırılması ve nadir de olsa saç tokası ısırması gibi faktörlerin mevcudiyetinde abrazyon lezyonları insizal kenarlarda çentik görüntüsünde de ortaya çıkabilir. ${ }^{19,24,25,34}$ Oklüzal abraziv lezyonlar ise, atrizyon varlığında görülen çukurlardan farklı olarak, abrazyonun tüm oklüzal tablayı etkilemesi nedeniyle aşınma alanları şeklinde görülür. ${ }^{5}$

\section{EROZYON}

Geleneksel olarak diş erozyonu, bakteriyojenik olmayan asitlerin neden olduğu diş sert dokusunun çözünmesi olarak tanımlanmaktadır. ${ }^{14,21,35-37}$

Erozyon, tüm dentisyonu etkileyebileceği gibi tek bir soliter lezyon olarak da lokalize olabilir. ${ }^{38}$ Erozyon genellikle diş yüzeyinin asidik maddelerle çözünmesi ile başlar. Asit atakları devam ettikçe, yüzeysel tabakanın çözünmesi devam eder ve bu tabaka tamamen ortadan kalkar. ${ }^{39,40}$ Erozyonun mine yüzeyini etkilemesiyle başlayan bu demineralizasyon süreci, temelde mine prizmasındaki çekirdek yapının veya interprizmatik alanların çözünmesinden kaynaklanmaktadır. ${ }^{30,35}$ Erozyonun sadece yüzeysel mine tabakasını değil, yaklaşık 0.02-3 $\boldsymbol{\mu} n$ derinliğe kadar diş dokularını etkileyebileceği unutulmamalıdır (Șekil 1). 9,15,21

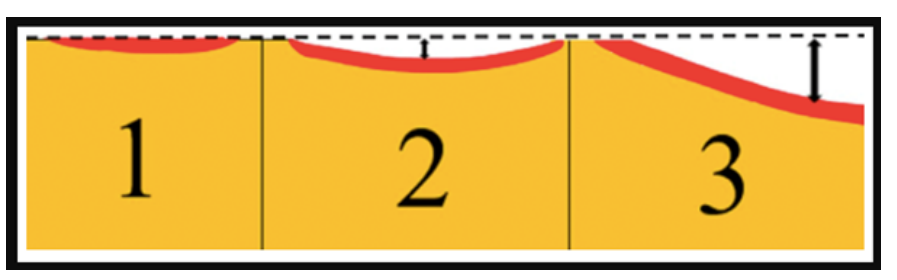

Şekil 1. Devam eden asit atakları ve ilerleyen erozyon varlığında diş yüzeyinde gözlemlenen değişimler: 1. Kırmızı ile simgelenmiş mine yüzeyinin materyal kay bı olmadan yumuşaması, 2. Kısmi materyal kaybı (Siyah ok) 3. Erozyonun devam etmesine bağlı ortaya çıkan aşırı materyal kaybı (Siyah ok). ${ }^{15}$

Erozyon etiyolojisinde yeri olan faktörler iç ve dış kaynaklar olarak sınıflandırılabilir. Gastroözefageal bozukluklar, spontan kusma, anoreksiya gibi kusmanın eşlik ettiği rahatsızlıklar, ruminasyon, gebelik, obezite ve ağız kuruluğunu indükleyen hastalıklar (Baş boyun bölgesi radyote- 
rapileri, tükrük bezi eksizyonları, Sjögren sendromu vb.) etiyolojideki iç kaynaklar olarak sıralanabilir. Düşük pH sahip ve $\mathrm{pH}$ değişikliklerine dirençli yiyecek ve içeceklerin sık tüketimi, çiğneme tableti veya efervesan içecek olarak kullanılan aspirin ve $\mathrm{C}$ vitamini, asidik $(\mathrm{pH}<5.5)$ oral hijyen ürünleri ve gargaraların kullanımı, ağız kuruluğunu indükleyen ve tükürük tamponlama kapasitesini etkileyen ilaçların (antidepresanlar vb.) kullanımı, asidik tükürük uyarıcılarının kullanımı, bulantı ve kusmaya neden olan ilaçlar, klorlu (zayıf tamponlanmış) yüzme havuzu suyunun yutulması (hidroklorik asit oluşumuna yol açar) ve asidik ortamlara maruz kalınan meslek gruplarında (Pil, akü fabrikası vb.) çalışmak gibi faktörler ise dış kaynakları oluşturmaktadır. $9,15,17,30,33,35,41-44$ Bu faktörlere ek olarak erozyonda oluşan hasarın boyutu, asidin tipi, konsantrasyonu, sıcaklığı, diş yüzeyleriyle temas süresi ve temas şekli gibi birçok etkene de bağlıdır. ${ }^{39,45}$

Minenin erozyona yatkın hale geldiği kritik pH'ın 5.5 olduğu tahmin edilmektedir. Bu nedenle, $\mathrm{pH}$ 'ı bu seviyede veya altında olan asidik bir malzeme mine ile sık sık ve uzun süre temas ettiğinde, mine erozyonu meydana gelecek ve mine yüzeyi etkenin gücü ve temas süresi ile ilişkili olarak mineral kaybına (demineralizasyona) uğrayacaktır. ${ }^{15,35}$ Çözünmeye başlamış mine tabakasının remineralizasyonu da mümkündür. Remineralizasyon, hidroksiapatit mineral tabakasını yeniden oluşturmak için minenin, kalsiyum ve fosfata maruz bırakılması sonucunda ortaya çıkabilir. Kalsiyum ve fosfat iyonları genellikle tükürükten veya diğer kaynaklardan elde edilir. ${ }^{46}$

Tükürüğün, erozyon nedeniyle ortaya çıkabilecek aşınmalara karşı koruyucu bir rolü vardır. Tükürük eroze mine ve dentinin yeniden remineralizasyon için kalsiyum, fosfat ve florür iyonları sağlayarak, ortamdaki asidi seyreltme ve yıkama özelliği sunarak demineralizasyon oranını azaltabilir. ${ }^{46,47}$ Asidik ağız ortamının neden olduğu mineral kaybının önlenebilmesi, tükürük pH'sına, türkrüğün bikarbonat içeriğine ve tamponlama kapasitesine, kalsiyum iyon konsantrasyonundaki değişikliklere ve tükürük akış hızına bağlıdır. Tüm bu faktörler tükürüğün doymuş durumuna dönme hızını etkileyerek, asit tehdidinden sonra mine yapısının remineralizasyon potansiyelini arttırır. Ayrıca, fırçalamadan hemen sonra oluşan tükürük pelikıl formasyonu da diş yüzeyine yapışarak yüzeyin doğrudan asit saldırısına karşı korunmasını sağlayan fiziksel bir bariyer oluşturur.9,48-51 Ancak tüm bu faktörlerin etkinliği bireysel değişiklikler sergileyebileceğinden, remineralizasyon ihtimali ve başarısı kişisel değişiklikler gösterir. ${ }^{46}$

Minenin remineralizasyon sürecinin devreye girememesi ve/veya etkenin tam anlamıyla uzaklaştırılamaması nedeniyle ortaya çıkan yüksek derecede demineralizasyon ile seyreden erozyon sonucunda, zarar görmüş mine yapısı hafif kuvvetler karşısında bile fiziksel olarak kırılgan ve kararsız hale gelir. ${ }^{40}$ Erozyonun erken evrelerinde, etkilenmiş mine tabakası genellikle gelişimsel çıkıntılardan yoksun, ince ve yarı saydam görüntüde, plak içermeyen, belirgin içbükey çukurlarla karakterize, pürüzsüz ve parlak bir yüzey halinde görülür. 10,52,53 Lezyonlar yaygın olarak maksiller dişlerin palatal ve oklüzal yüzeylerinin yanı sıra mandibular posterior dişlerin de bukkal ve oklüzal yüzeylerinde gözlemlenebilir. Bu spesifik görüntü tıbbi bir durumla bağlantılı olabilir.10 Örneğin, gastroözofageal bozukluğun neden olduğu, "perimoliz veya perimiloliz" olarak adlandırılan erozyon defektleri bu tarz erozyon tipine en güzel örnektir. Gastroözefageal bozuklukta açığa çıkan intrinsik asit, mideden yemek borusuna geçen ve ağza ulaşan mide asididir ve $\mathrm{pH}$ değeri çok düşük olan bu sıvı, hidroklorik asit ve düşük konsantrasyonlarda kalsiyum-fosfat içerir. ${ }^{35,42,43} \mathrm{Bu}$ asidik ortam nedeniyle ortaya çıkan erozyon lezyonları genellikle, üst ön dişlerin palatinal yüzeylerinde lokalize olurken, yüzeylerini dilin örtülemesi dolayısıyla genellikle alt posterior dişler bu durumdan daha az etkilenir. ${ }^{17,22,24}$ Asidik içecekler ile ilişkili diyet, bu tip içeceklerin ağız içinde uzun süre bekletilmesi veya asidik içecekler ile ağzın çalkalanması gibi etkenlerden kaynaklanan diğer bir erozyon tipinin ise daha fazlasıyla maksiller dişlerin labial yüzeylerini etkilediği bilinmektedir. ${ }^{10,22,54,55}$ Erozyonun neden olduğu diş aşınmalarının belirtileri ayrıntılı olarak incelendiğinde ise erozyon lezyonlarının genellikle yuvarlak kenarlı olduğu, oklüzal yapıların düzleştiği, tüberkül yapılarının ortadan kalktığı ve şiddetli vakalarda oklüzal anatominin tamamen kaybolduğu, lingual ve labial yüzeylerin düzleşmiş görüntüsünün yanında bazen dişeti kenarı boyunca sağlam bir mine hattının gözlenebileceği, okluzal dikey boyutta (ODB) azalma ve interokluzal mesafede bir artış oluşabileceği, lezyonların simetrik veya asimetrik olarak dağılabileceği ve etkene bağlı olarak sık görüldüğü lokasyonların değişebileceği görülmüştür. ${ }^{46}$

Erozyon yavaşça geliştiğinde lezyonlar genellikle asemptomatiktir ve bu nedenle hasta fark etmeden ilerlemeye devam edebilir. ${ }^{33}$ Erozyon lezyonları bazen abrazyonlarla karıştırılabilir. Bu iki lezyon tipinin ayırıcı tanısında kritik öneme sahip iki temel özellik vardır. Erozyon aktif olduğunda, lezyonlara genellikle dentin hassasiyeti eşlik ederken, abrazyon lezyonları dentin hassasiyeti ile ilişkili değildir. Abrazyonda hipersensivitenin olmayışı, açığa çıkan dentin dokusundaki dentinal tübülleri bloke eden mekanik bir smear tabakasının oluşumu ile ilişkilendirilir. Ayrıca, erozyon ve abrazyonda oluşan lezyonlar karşılaştırıldığında, erozyondaki lezyonların derinliğinin abrazyonda görülen lezyonlardan daha fazla olduğu tespit edilmiştir. Bu iki faktörün ayrıntılı incelenmesi, aşınma nedeninin belirlenmesinde ve doğru tanı-tedavi uygulanmasında önem arz etmektedir. ${ }^{5}$

\section{ABFRAKSIYON}

Abfraksiyon, keskin çizgi açılarına sahip, marjinal dişetinin altında da konumlanabilen, kama şeklindeki patolojik 
doku kaybı anlamına gelir. ${ }^{38}$ Protez Terimleri Sözlüğü 'ne (2017) göre abfraksiyon, biyomekanik yükleme kuvvetlerinin neden olduğu diş sert dokusunun patolojik kaybı olarak tanımlanır. ${ }^{56}$ Abfraksiyon lezyonlarının etiyolojisi tam olarak bilinmiyor olsa da konuyla ilgili çok sayıda hipotez mevcuttur. ${ }^{57}$ Genel olarak literatürde abfraksiyonun, atipik oklüzal kuvvetler ile ilişkili olduğunu görüşü hakimdir ve bu tür sert diş dokusu kayıplarının, gerçek oklüzal yükleme noktasından uzak bir yerde, mine ve/veya dentinin aşırı makaslama kuvvetine maruz kalması ve buna bağlı olarak oluşan kimyasal yorgunluk bozulmasının bir sonucu olarak ortaya çıktığı düşünülmektedir.,13

Çiğneme ve parafonksiyonlar sırasında dişler üzerinde oluşan lateral oklüzal kuvvetler özellikle dişlerin servikal bölgesinde gerilme streslerinin ortaya çıkmasına neden olur. Minenin sıkışma (baskı) kuvvetleri karşısında dayanıklı, ancak gerilme (çekme) kuvvetleri karşısında dayanıksı olduğu bilinmektedir ve istenmeyen oklüzal kuvvetler sonrasında oluşan bu gerilme stresleri, servikal bölgede mine ve dentin yapısındaki hidroksiapatit kristallerinde mikro çatlak oluşmasına ve diş dokuları arasında bulunan kimyasal bağların bozulmasına yol açar. Bununla birlikte, çiğneme ve parafonksiyonlar sonucunda oluşan lateral kuvvetlerin yönünün, büyüklüğünün ve etki süresinin, abfraksiyon lezyonunun pozisyonunu yönettiği ve lezyonun büyüklüğü üzerinde etkili olduğu ileri sürülmektedir. ${ }^{19,22,39,58,59}$ Ancak, oklüzal kuvvetlerin abfraksiyonun ana nedeni olduğunu söylemek için halen literatürdeki veriler yetersizdir. ${ }^{40,60}$

Klinik olarak servikal abfraksiyon lezyonları dişlerin labial yüzeylerinde gözlenir. Tipik olarak, abrazyon lezyonlarına benzeyen, kama veya $\mathrm{V}$ şekilli lezyonlardır ve bu benzerlik abrazyon ve abfraksiyon lezyonlarının klinik ayırıcı tanısını oldukça zorlaştırır. ${ }^{11}$ Ancak abfraksiyon lezyonlarının dişeti seviyesinin altına doğru da uzanabiliyor olması bazı vakalarda abfraksiyon ve abrazyon lezyonlarının ayrımını kolaylaştırır. ${ }^{7.38}$

Kısacası, bahsedilen tüm aşınma tiplerinin ortaya çıkışında farklı etiyolojik nedenler mevcuttur ve lezyonların klinik görüntüleri genellikle birbirinden farklıdır. Ancak lezyonlar ağızda tek başlarına görülebilecekleri gibi dört tip aşınma eş zamanlı olarak da ortaya çıkabilir. Lezyonların kombine görüldüğü olgularda etkenin teşhisi ve tercih edilecek tedavi seçeneğine karar verilebilmesi oldukça karmaşık ve zor bir durumdur. ${ }^{15,33,43,62,63}$ Bu nedenle diş aşınmalarının teşhisinde uluslararası geçerliliği olan değerlendirme skalalarının oluşturulması çok önemlidir.

\section{Diş AŞINMASININ TEŞHISINDE KULLANILABILECEK INDEKSLER}

Günümüze kadar diş aşınmalarını teşhis etme noktasında klinisyenlere yardımcı olmak için çok sayıda indeks geliştirilmiştir. Broko tarafından belgelenen en eski indeksin, etiyolojiyi varsaymadan, horizontal veya oblik oklüzal aşınma modellerini içerdiği bilinmektedir ve bu indeks günümüzde kullanılan diğer birçok indeksin geliştirilmesinde kullanılmıştır. ${ }^{64}$

Smith ve Knight tarafından 1984 yılında geliştirilen ve günümüzde halen epidemiyolojik çalışmalarda sıklıkla kullanılan bir diğer indeks ise "Diş Aşınma Inndeksi (Tooth Wear Index, TWI)" dir. ${ }^{31}$ Bu indeks çok faktörlü diş aşınmalarını ölçmek ve izlemek için tasarlanmış ilk indekstir. İndeks ile etkene bakılmaksızın, dişlerin dört yüzeyinin de aşınma miktarlarının ölçümüne ilişkin genel bir klinik bakış açısı oluşturulmuştur (Tablo 1).31,65

Tablo 1. Smith ve Knight' ın tasarladığı Diş Aşınma İndeksi (DAi).

\begin{tabular}{|c|c|c|}
\hline SKOR & YÜZEY & KRITER \\
\hline 0 & $\mathrm{~B} / \mathrm{L} / \mathrm{O} / \mathrm{I} / \mathrm{S}$ & $\begin{array}{l}\text { - Mine yüzcy özelliklerinde kayıp yok } \\
\text { - Diş konturunda kayıp yok }\end{array}$ \\
\hline 1 & $\mathrm{~B} / \mathrm{L} / \mathrm{O} / \mathrm{I} / \mathrm{S}$ & $\begin{array}{l}\text { - Mine yüzcyinin karakteristik özelliklerinde kayıp } \\
\text { - Diş yapısında minimum kontur kaybı }\end{array}$ \\
\hline 2 & $\mathrm{~B} / \mathrm{L} / \mathrm{O} / \mathrm{I} / \mathrm{S}$ & $\begin{array}{l}\text { - Yũzeyin üçte birinden daha az alanda açığa çıkmış dentin } \\
\text { yapısı ile scyreden mine kaybı } \\
\text { - Sadece dentinin açığa çıktı̆ı mine kaybı } \\
\text { - Derinliği } 1 \text { mm'den az defektlerin varlığı }\end{array}$ \\
\hline 3 & $\mathrm{~B} / \mathrm{L} / \mathrm{O} / \mathrm{I} / \mathrm{S}$ & $\begin{array}{l}\text { - Yũzeyin üçte birinden daha fazla alanda açı̌̆a çıkmış dentin } \\
\text { yapısı ile seyreden mine kaybı } \\
\text { - Mine ve dentin yapısında ónemli ơlçüde kayıp } \\
\text { - Derinliği } 2 \text { mm'den az defektlerin varlığı }\end{array}$ \\
\hline 4 & $\mathrm{~B} / \mathrm{L} / \mathrm{O} / \mathrm{H} / \mathrm{S}$ & $\begin{array}{l}\text { Minenin tamamen kaybedilmesi ile beraber pulpanın ve } \\
\text { sekonder dentinin açığa çıkması } \\
\text { - Pulpanın veya sekonder dentinin açı̆̆a çıkması } \\
\text { - } 2 \text { mm'den daha derin defektler ile beraber pulpanın ve sekonder } \\
\text { dentinin açığa çıkması }\end{array}$ \\
\hline
\end{tabular}

Bununla birlikte bu indeks, restorasyonlu dişler için bir skorlamaya sahip olmaması, tüm dentisyon için uygulama süresinin uzun olması ve değerlendirmenin sadece klinisyenin defekti görsel olarak tanımlayabilmesine bağlı olması gibi nedenlerden ötürü dezavantajı bulunmaktadır. ${ }^{65}$ Ayrıca bu indekse göre tam mine kaybı (skor 4) tanımlamasının, aşınmış yüzey sınırlarının neredeyse her zaman bir mine tabakasıyla (mine halkasıyla) çevrili olması dolayısıyla yanıltıcı olabileceği de düşünülmektedir. ${ }^{64}$ McCay ve ark., ${ }^{66}$ özellikle azı dişlerinin lingual yüzeylerinde gözlenen eroziv tahribatın şiddetini değerlendirmek için farklı bir indeks geliştirmiştir. Altı puanlı derecelendirmeyi içeren bu sistemde araştırıcılar, dört molar bölge için verilen eroziv aşınma puanlarının ortalamasını toplayarak, erozyona ait genel bir skor elde etmeyi hedeflemiştir. Bu metot ile olgunun analizi için basit veriler elde edilirken, bu şekilde ortalama puanlar üzerinden değerlendirme yapılmasının büyük oranda veri kaybına yol açtığı kabul edilmektedir. Çünkü bu sisteme göre, değerlendirilen olguda erozyondan aşırı şekilde etkilenmiş olan dişler mevcut olsa dahi, eğer etkilenen diş sayısı az ise, indekste ortalama puan hesaplaması üzerinden analiz yapıldığın- 
dan, hastaya ait total erozyon skoru mevcut durumu yansıtmayacak şekilde daha düşük olarak hesaplanacaktır. Hesaplanan bu düşük skor, lokalize bir klinik problemin maskelenmesine neden olacağından, teşhisin doğru yapılabilmesi ve problemin şiddetinin doğru belirlenebilmesi açısından sakıncalıdır.6 6

Eccles tarafından erozyona yönelik geliştirilen başka bir indekste de lezyonlar erken, küçük ve gelişmiş lezyonlar olarak sınıflanmış ve daha sonra indekse tanımlayıcı kriterler eklenerek indeks genişletilmiştir. ${ }^{67}$ Geliştirilen bu indeks, özellikle endüstriyel olmayan nedenlerden dolayı ortaya çıkan erozyon lezyonlarını hem lezyonun şiddeti hem de lokasyonu açısından derecelendiren kapsamlı ve kalitatif bir indeks olarak sunulmuştur. İndeks temelde erozyon lezyonlarını üç farklı sınıf altında incelemiştir (Tablo 2).

Tablo 2. Endüstriyel kaynaklı olmayan diş erozyonu için Ecdes endeksi

\begin{tabular}{|c|c|c|}
\hline SINIF & YÜZEY & KRITER \\
\hline Smf I & & $\begin{array}{l}\text { - Erozyonun crken așamalanı } \\
\text { - Gelișimsel sırtlann olmaması } \\
\text { - Ozellikle maksiller kesici ve kanin dişlerinde pürūzsūz yüzeyler }\end{array}$ \\
\hline Simf II & Fasiyal & $\begin{array}{l}\text { - Yüzeyin üçte birinden daha az alanda dentin dokusu varlı̣̆ı } \\
\text {-Tip } 1 \text { (en yaygın): } \\
\text { - Ana hatta oval görünüm } \\
\text { - Konkav kama şeklindeki abrazyon lezyonlarından farklıdır. } \\
\text { - Tip 2: } \\
\text { - Tamamen minc içinde lokalize olan dũzensiz lezyonlar } \\
\text { - Dış yưzcyde dclikli görunuum }\end{array}$ \\
\hline $\begin{array}{l}\text { Simif } \\
\text { IIIa }\end{array}$ & Fasiyal & $\begin{array}{l}\text { - Ōzellikle ōn dișlerin yūzeyinde geniş dentin hasarı } \\
\text { - Bazı lezyonlar lokalize seyreder ve çukur formundadır. }\end{array}$ \\
\hline $\begin{array}{l}\text { Sinuf } \\
\text { IIIb }\end{array}$ & $\begin{array}{l}\text { Lingual } \\
\text { veya } \\
\text { palatinal }\end{array}$ & $\begin{array}{l}\text { - Dentin yüzey alanının ụçte birinden daha fazlasında kayıp. } \\
\text { - Insizal kenarda oluşan dũzleșme ya da çukur alanlar sebebiyle } \\
\text { dişin translúsensisinde kayıp, } \\
\text { - Sekonder dentin içine kadar uzanana kayıp alanlan }\end{array}$ \\
\hline Simif IIIc & $\begin{array}{l}\text { Insizal veya } \\
\text { oklüzal }\end{array}$ & $\begin{array}{l}\text { - Dentin içerisine uzanan, düzleşmiş veya çukur alanlar } \\
\text { - Zayıf mine yapısı } \\
\text { - Diş dokusunda oluşan aşımmaya bağlı olarak ortaya çıan } \\
\text { yükselmiş restorasyonlar }\end{array}$ \\
\hline $\begin{array}{l}\text { Sinuf } \\
\text { IIId }\end{array}$ & $\begin{array}{l}\text { Tüm } \\
\text { yüzeyler }\end{array}$ & $\begin{array}{l}\text { - Hem labial hem de lingual yũzeylerin ciddi şekilde etkilendiǧ́ } \\
\text { olgular } \\
\text { - Boyca kısalmış dişler }\end{array}$ \\
\hline
\end{tabular}

Ayrıca bu indeks devamında geliştirilen indeksler için de ana yol gösterici olmuştur. ${ }^{67,68}$ Ancak temelde sadece erozyon lezyonlarının sınıflamasına uygun olan bu indeks tüm klinik vakalar için yetersiz kalmıştır. ${ }^{69}$

Karmaşık ve uzun değerlendirme indekslerinin klinik kullanımının zor olacağı görüşüyle, Bardsley ve ark. ${ }^{69}$ ise oldukça basit bir indeks geliştirerek, klinik sınıflamayı kolaylaştırma yolunu seçmiştir (Tablo 3).
Tablo 3. Diş aşınma indeksi için basitleştirilmiş puanlama kriterleri

\begin{tabular}{ll}
\hline SKOR & KRITER \\
\hline $\mathbf{0}$ & Dentin içerisinde aşımma yok. \\
$\mathbf{1}$ & Dentin sadece gŏrülebilir (çukurluk dahil) veya dentin açığa çıkmıș. \\
$\mathbf{2}$ & Yüzeyin $1 / 3$ 'ủnden daha fazla dentin açığa çıkmıștır. \\
3 & Pulpa veya sekonder dentinin açığa çıkması. \\
\hline
\end{tabular}

Bartlett ve ark. ${ }^{2}$ tarafından 2008 yılında tanımlanan "Temel Eroziv Aşınma Muayenesi (Basic Erosive Wear Examination, BEWE)" indeksi ise, hastanın diş aşınması açısından risk seviyesini sınıflandırmak amacıyla geliştirilmiştir. Bu indeks aşınma sınıflamasını, lezyonun derinliğinden, dentin veya pulpanın lezyondan etkileyip etkilemediğinden ziyade, lezyondan etkilenen ölçülebilir yüzey alanına göre tanımlamıştır. Bu amaçla her bir bölge için en fazla etkilenen dişin incelenmesi ve etkilenmiş dişlerin, 0 (aşınma yok), 1 (ilk yüzey dokusu kaybı), 2 (\% 50'den az yüzey kaybı) ve 3 (\% 50'den fazla yüzey kaybı) olarak derecelendirilmesini hedeflemiştir.2 Bu yöntem, diş aşınmasının erken teşhisinde ve takibinde yararlı olabilecek bir yöntemdir ve ağız içi tarayıcılarla elde edilen 3 boyutlu görüntülerle birleştirildiğinde özellikle lezyonların takibinde oldukça etkilidir. ${ }^{70,71} 2010$ yılında ise Vailati ve Belser tarafından "Anterior Klinik Eroziv Sınıflandırma (Anterior Clinical Erosive Classification, $\mathrm{ACE})^{\prime \prime}$ indeksinin kullanımı önerilmiştir. Bu indeks özellikle üst anterior dişlerin palatinal yüzeyinde, mine ve dentin hasarının yanı sıra diş vitalitesinin korunmasına göre aşınmanın sınıflandırmasını hedeflemiştir. ${ }^{72}$ Tüm bu indeksler lezyonun teşhisinde ve takibinde bir takım avantaj ve dezavantajlara sahiptir. Aslında klinisyenler için en önemlisi, teşhisin yanı sıra tedavi rehberliği de sağlayabilecek indekslerin geliştirilmesidir. Bu amaçla geliştirilen "Diş Aşınma Değerlendirme Sistemi (Tooth Wear Evaluation Systems, TWES)", teşhis sürecini optimize etmek için hazırlanan ve farklı modüler içeren klinik bir kılavuzdur (Şekil 2). ${ }^{36}$

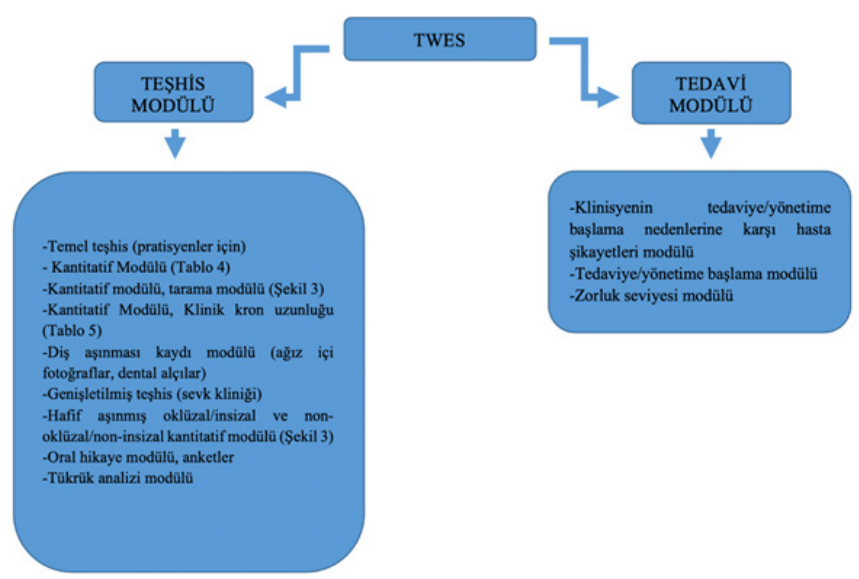

Şekil 2. Diş aşınma değerlendirme sistemi (TWES) ve sistem modülleri 
Mevcut modüller ile problemi tanımak (nitelendirmek), şiddetini derecelendirmek (nicelleştirmek), olası nedenleri teşhis etmek ve durumu izlemek (ilerlemek) mümkündür. Bunun yanı sıra, tedaviye ne zaman başlanacağını belirlemek, hangi tedavinin uygulanacağına karar vermeye ve restoratif tedavinin zorluk seviyesini tahmin etmeye de imkan sunmaktadır. ${ }^{36}$

TWES sisteminde ilk adım diş aşınması alt tiplerinin klinik görünümlerinin belirlenmesini içerir. Bu amaçla Gandara ve Truelove tarafından, diş aşınma tipleriyle ilgili klinik işaretlerin kapsamlı bir listesi hazırlanmıştır (Tablo 4). ${ }^{73}$

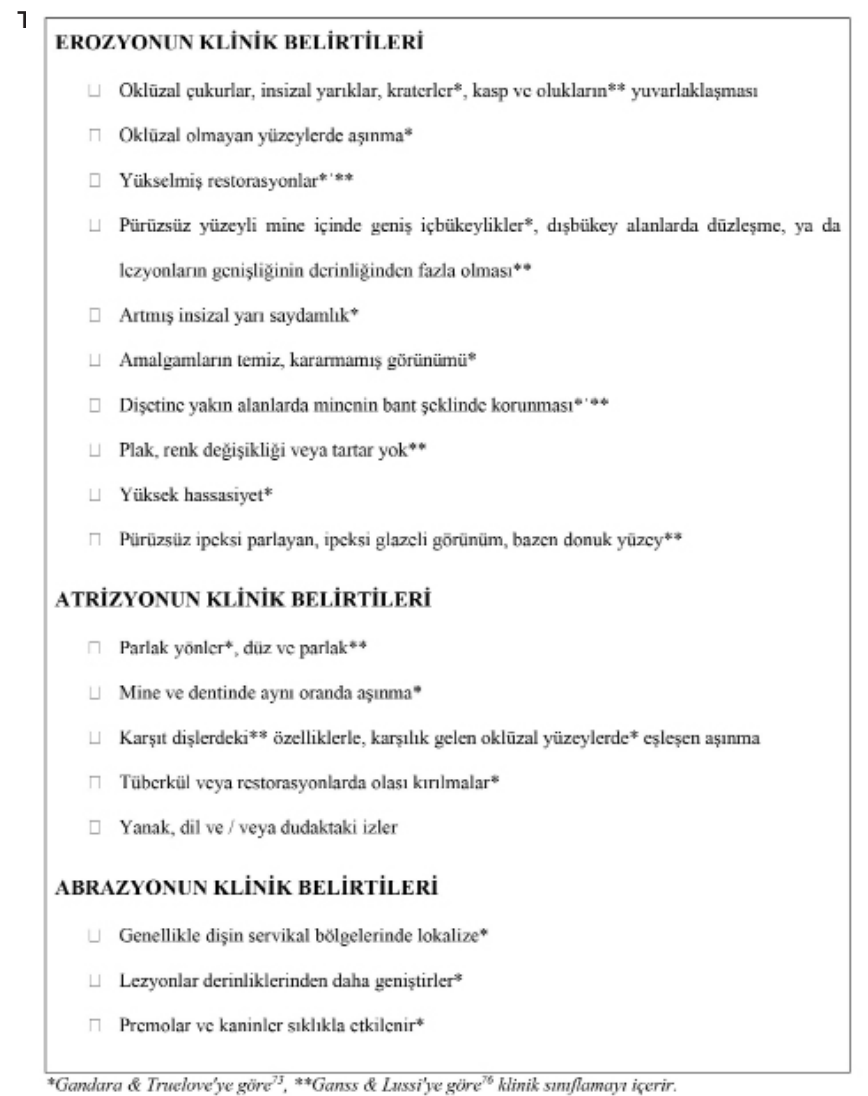

Listelenen klinik işaretlerin çoğu sadece geçmişte veya günümüzde ortaya çıkan morfolojik değişiklikleri tespit etmemize yardımcı olurken, duyarlıık ve/veya ağrı ve plak, tartar veya lekelenmenin olmaması klinisyene eroziv sürecin hala aktif olduğunu düşündürmelidir. ${ }^{36}$

TWES indeksine göre diş aşınmasının nitelendirilmesinden sonraki adım, aşınmanın şiddetinin derecelendirilmesidir. TWES sistemi içerisindeki nicelik tarama modülü, bu amaç için kullanımı kolay ve hızlı bir modüldür (Şekil 3).

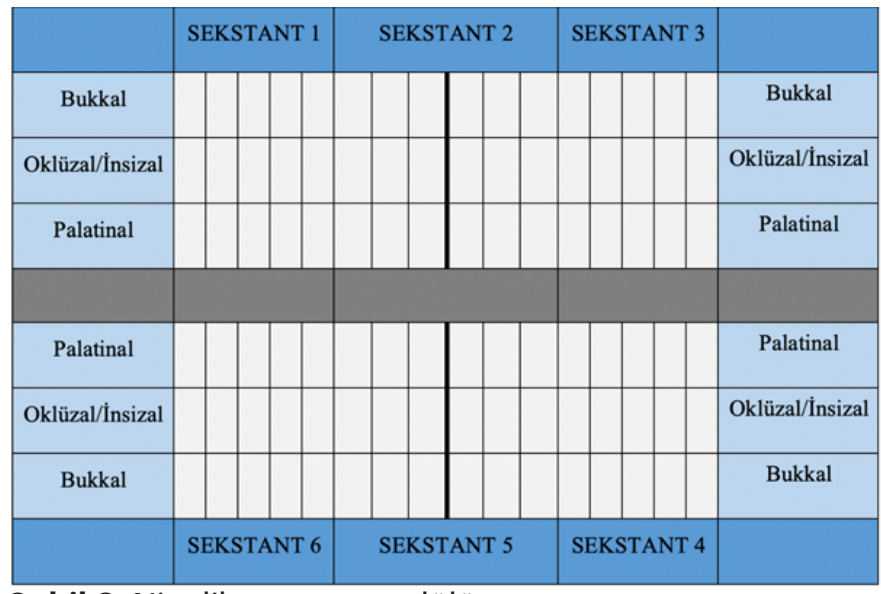

Şekil 3. Nicelik tarama modülü tarama şeması

Bu modül kapsamında her bir sekstant için, oklüzyon ve artikülasyonda rol oynayan yüzeyler derecelendirilir. Ardışık altı sekstant için oklüzal/insizal yüzeyler, derecelendirme skalası kullanılarak derecelendirilir. Bu derecelendirmeye göre, $0=$ =aşınma yok; $1=$ =mine ile sınırlı aşınma; 2=kuron yüksekliğinde değişiklik yaratan $1 / 3$ oranında dentin dokusunda aşınma, $3=$ kron yüksekliğinin $1 / 3^{\prime}$ ünden fazla ancak $2 / 3$ 'ünden az doku aşınması; 4=kron yüksekliğinin $2 / 3$ 'ünden fazlasının aşınmasını ifade etmektedir.74 Bu modülde ek olarak, ikinci sekstant da dişlerin artikülasyonda önemli rolü olan palatinal yüzeyleri

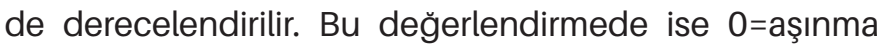
yok; 1=mine ile sınırlı aşınma; 2=dentin dokusunun açığa çıkması şeklindeki puanlama esas alınır. ${ }^{36}$ Bu derecelendirme metodunda her bir sekstant için çeşitli skorlar ayrı ayrı kaydedilir ve toplanmaz. Bu özelliği ile TWES indeksi aşınma derecelerinin maskelenmesinin önüne geçilebilmesini sağlar. ${ }^{2}$

Değerlendirme sonucunda eğer dentinin bir veya daha fazla sekstantta aşınmaya maruz kaldığı tespit edilirse (derece 2 veya daha fazla), bir sonraki adım olan kantitatif Modülü, Klinik kron uzunluğu hesaplama modülüne geçilir. Bu adımda alt ve üst tüm anterior dişlerin (dört köpek dişinin ve ikinci ve beşinci sekstantın sekiz kesici dişin) klinik kron uzunluğu hesaplanır. Mevcut durumdaki diş kron yükseklikleri periodontal sond ya da kumpaslarla ölçülerek kaydedilir (Tablo 5).

\begin{tabular}{|c|c|c|c|c|c|c|}
\hline Diş Numaraları & 13 & 12 & 11 & 21 & 22 & 23 \\
\hline Ortalama Yükseklik & $11 \mathrm{~mm}$ & $10 \mathrm{~mm}$ & $12 \mathrm{~mm}$ & $12 \mathrm{~mm}$ & $10 \mathrm{~mm}$ & $11 \mathrm{~mm}$ \\
\hline \multicolumn{7}{|l|}{ Ölçülen Diş Yükssekliği } \\
\hline Diş Numaraları & 43 & 42 & 42 & 31 & 32 & 33 \\
\hline Ortalama Yükseklik & $11 \mathrm{~mm}$ & $10 \mathrm{~mm}$ & $10 \mathrm{~mm}$ & $10 \mathrm{~mm}$ & $10 \mathrm{~mm}$ & $11 \mathrm{~mm}$ \\
\hline Olçülen Diş Yüksekliğ & & & & & & \\
\hline
\end{tabular}

Böylece aşınmanın ortalama diş yüksekliğine göre hangi seviyede olduğu da sayısal olarak tespit edilebilir.

Diş aşınması ile karşı karşıya olan hasta gruplarının her 
randevusunda mevcut diş durumlarının kaydedilmesi şarttır. Bunun yanı sıra, ağız içi fotoğraflarla birlikte çalışma modellerinin (veya mümkün olduğunda dijital modeller için taramalar) elde edilmesi de çok önemlidir. Ağız içinden gözle muayene ile yapılan puanlamanın, dental çalışma modelleri kullanılarak yapılan puanlamaya göre daha güvenilir olduğu gösterilmiştir, ancak her iki yaklaşım için de güvenilirlik yeterlidir. ${ }^{36}$ Ağız içi fotoğraflar ile yapılan puanlamanın ise ağız içi puanlamaya kıyasla daha güvenilir olduğunu göstermiştir. ${ }^{75} \mathrm{Bu}$ nedenle hastaların kontrolünde her üç teknikle de uyumlu bir puanlama sisteminin kullanılması faydalı olacaktır.

Teşhis modülünün son kısmında ise TWES sistemi, tüm bu sayısal veri analizlerinin yanı sıra hastaların sistemik öyküleri ve tükürük kalitesi, miktarı ve akış hızı gibi diş aşınma oranlarını etkileyebilecek hastaya özgü bireysel analizlerin de yapılmasını önermektedir. ${ }^{36}$ Tüm modüllerin tamamlanması sonrasında TWES sistemi hastanın diş aşınmasını şu özet formatta sınıflamaktadır. Bu formata göre diş aşınmaları,

1. Dağılımına göre;

-Lokalize (1 veya 2 sekstant)

-Genelleşmiş (3-6 sekstant)

2. Şiddetine göre;

- Hafif (mine içinde aşınma; oklüzal/insizal ve/veya oklüzal olmayan/insizal olmayan)

- Orta (dentinin açığa çıktığı aşınma; oklüzal/insizal ve/ veya oklüzal olmayan/insizal olmayan)

- Şiddetli (dentinin açığa çıktığı aşınma ve klinik kron yüksekliği kaybı <2/3 olan aşınma)

- Aşırı (dentinin açığa çıktığı aşınma ve klinik kron yüksekliği kaybı $\geq 2 / 3$ olan aşınmalar)

3. Kökene göre;

- Mekanik/içsel (atrizyon)

- Mekanik/dışsal (abrazyon)

- Kimyasal/içsel (erozyon)

- Kimyasal/dışsal (erozyon) olarak sınıflandırılacaktır.

Ancak TWES sistemi birçok avantajının yanı sıra, oldukça ayrıntılı bir diş aşınma değerlendirme sistemi olduğundan ve hasta muayenesi esnasında çok fazla aşama içermesinden dolayı hekimler tarafından klinik kullanım açısından kullanımı zor bulunan bir sistemdir. Bilimsel araştırma çalışmaları için ise bu sistem oldukça gelişmiş ve yol göstericidir. ${ }^{36}$

Özetle, tüm diş aşınmalarının temelinde farklı etiyolojik nedenler mevcut olsa da lezyonların eş zamanlı olarak da ortaya çıktığı olgularda etkenin teşhisi ve derecelendirilmesi oldukça zordur. ${ }^{15,33,43,62,63}$ Bu nedenle, diş aşınmalarının doğru teşhis edilebildiği, önlenebildiği ve yönetilebildiği sağlam bir klinik yaklaşım esastır. Bu yaklaşım diş hekimlerinin konu hakkında bilgi sahibi olmalarını gerektirirken, bu yaklaşımın sağlanabilmesi de ancak teşhis ve tedavi planlaması noktasında uluslararası geçerliliği olan değerlendirme skalalarının oluşturulmasının yanı sıra tedavi planlaması ve klinik iş akışının profesyonelleştirilmesi ile mümkündür. ${ }^{33} \mathrm{Bu}$ amaca yönelik literatürde çok sayıda indeks mevcut olsa da günümüzde tüm klinik intiyaçları tek bir indekste toplayan kabul edilmiş evrensel bir sınıflama sistemi mevcut değildir. Bu nedenle mevcut indeksler içerisinden, diş aşınmalarının sınıflandırılması, teşhisi, tedavi planlaması ve takibi için kullanılabilecek en basit ve kapsamlı indeksten faydalanılması en doğru yaklaşım olacaktır.

\section{KAYNAKLAR}

1. Haddadin K, Rassas $\mathrm{E}$, Masarweh $\mathrm{N}$, Haddadin $\mathrm{KH}$. Causes for tooth surface loss in a group of Jordanian population. Pak Oral Dent J 2015;35:129-134.

2. Bartlett $D$, Ganss $C$, Lussi A. Basic Erosive Wear Examination (BEWE): A new scoring system for scientific and clinical needs. Clin Oral Investig 2008;12:8-65.

3. Bassiouny MA. Effect of sweetening agents in acidic beverages on associated erosion lesions. Gen Dent 2012;60:30-322.

4. Rashid H, Hanif A, Nasim M. Tooth surface loss revisited: Classification, etiology, and management. J Restor Dent 2015;3:37-43.

5. Kaidonis JA. Tooth wear: The view of the anthropologist. Clin Oral Investig 2008; 12: 6-21.

6. Van't Spijker A, Rodriguez JM, Kreulen CM, Bronkhorst EM, Bartlett DW, et al. Prevalence of tooth wear in adults. Int J Prosthodont 2009;22:35-42.

7. Davies SJ, Gray RJM, Qualtrough AJ. Management of tooth surface loss. Br Dent J 2002;192:11-23.

8. Bartlett DW, Fares J, Shirodaria S, Chiu K, Ahmad N, et al. The association of tooth wear, diet and dietary habits in adults aged 18-30 years old. J Dent 2011;39:811-816. 9. Lussi A. Erosive tooth wear-A multifactorial condition of growing concern and increasing knowledge. Monogr Oral Sci 2006;20:1-8.

10. Azouzi I, kalghoum I, Hadyaoui D, Harzallah B, Cherif $M$. Principles and guidelines for managing tooth wear: $A$ review. Intern Med Care 2018;2:1-9.

11. Al-Zarea, Bader K. Tooth surface loss and associated risk factors in Northern Saudi Arabia. ISRN Dent 2012;1-5. 12. Smith BGN, Bartlett DW, Robb ND. The prevalence, etiology and management of tooth wear in the United Kingdom. J Prosthet Dent 1997;78:367-372.

13. Wood I, Jawad Z, Paisley C, Brunton P. Non-carious cervical tooth surface loss: A literature review. J Dent 2008;36:759-766.

14. Lussi A, Carvalho TS. Erosive tooth wear: A multifactorial condition of growing concern and increasing knowledge. Monogr Oral Sci 2014;25:1-15.

15. Lussi A, Schlueter N, Rakhmatullina E, Ganss C. Dental erosion-An overview with emphasis on chemical and histopathological aspects. Caries Res 2011;45:2-12. 
16. Grippo JO. Abfractions: A new classification of hard tissue lesions of teeth. J Esthet Dent 1991;3:14-19.

17. Hobkirk JA. Tooth surface loss: causes and effects. Int J Prosthodont 2007;20:340-341.

18. Mair LH. Wear in dentistry-current terminology. J Dent 1992;20:140-144.

19. Chu FCS, Yip HK, Newsome PRH, Chow TW, Smales RJ. Restorative management of the worn dentition: I. Aetiology and diagnosis. Dent Update 2002;29:162-168.

20. Milosevic A, O'Sullivan E. Diagnosis, prevention and management of dental erosion: summary of an updated national guideline. Prim Dent Care 2008;15:11-12.

21. Addy $M$, Shellis RP. Interaction between attrition, abrasion and erosion in tooth wear. Monogr Oral Sci 2006;20:17-31.

22. Alhilou A, Beddis HP, Mizban L, Seymour DW. Basic Erosive Wear Examination: assessment and prevention. Dent Nurs 2015;11:262-267.

23. Ceruti $P$, Menicucci $G$, Mariani GD, Pittoni $D$, Gassino G. Non carious cervical lesions. A review. Minerva Stomatol 2006;55:43-57.

24. Litonjua LA, Andreana S, Bush PJ, Cohen RE. Tooth wear: Attrition, erosion, and abrasion. Quintessence Int 2003;34:435-446.

25. Imfeld T. Dental erosion. Definition, classification and links. Eur J Oral Sci 1996;104:151-155.

26. Lee WC, Eakle WS. Stress-induced cervical lesions: review of advances in the past 10 years. J Prosthet Dent 1996;75:487-494.

27. Litonjua L, Andreana S, Cohen R. Toothbrush abrasions and noncarious cervical lesions: evolving concepts. Compend Contin Educ Dent 2005;26:767-773.

28. Mahalick JA, Knap FJ, Weiter EJ. Occusal wear in prosthodontics. J Am Dent Assoc 1971;82:154-159.

29. Turner KA, Missirlian DM. Restoration of the extremely worn dentition. J Prosthet Dent 1984;52:467-474.

30. Levrini L, Di Benedetto G, Raspanti M. Dental wear: a scanning electron microscope study. Biomed Res Int 2014;2014:340425.

31. Smith BG, Knight JK. A comparison of patterns of tooth wear with aetiological factors. Br Dent J 1984;157:16-19. 32. Smith BG. Toothwear: aetiology and diagnosis. Dent Update 1989;16:204-212.

33. Warreth A, Abuhijleh E, Almaghribi MA, Mahwal G, Ashawish A. Tooth surface loss: A review of literature. Saudi Dent J 2020;32:53-60.

34. Rath A, Ramamurthy PH, Fernandes BA, Sidhu P. Effect of dried sunflower seeds on incisal edge abrasion: A rare case report. J Conserv Dent 2017;20:134-136.

35. Meurman JH, Gate JM. Pathogenesis and modifying factors of dental erosion. Eur J Oral Sci 1996;104:199206.

36. Wetselaar P, van der Zaag J, Lobbezoo F. Tooth wear, a proposal for an evaluation system. Ned Tijdschr Tandheelkd 2011;118:324-328.

37. Eccles JD. Tooth surface loss from abrasion, attrition and erosion. Dent Update 1982;9:373-381.

38. Goldstein RE, Curtis JW, Farley BA, Siranli S, Clark WA. Abfraction, Abrasion, Attrition, and Erosion. In: Goldstein RE, Chu SJ, Lee EA, Stappert CFJ, editors. Esthetics in dentistry. 3th ed. John Wiley \& Sons, Inc.; 2018. p. 692 719.

39. Barbour ME, Rees GD. The role of erosion, abrasion and attrition in tooth wear. J Clin Dent 2006;17:88-93.

40. Eisenburger M. Degree of mineral loss in softened human enamel after acid erosion measured by chemical analysis. J Dent 2009;37:491-4.

41. Claffey N. Essential oil mouthwashes: A key component in oral health management. J Clin Periodontol 2003;30:22-24.

42. Dawes $\mathrm{C}$. What is the critical $\mathrm{pH}$ and why does a tooth dissolve in acid? J Can Dent Assoc 2003;69:722-724.

43. O'sullivan E, Milosevic A. UK National Clinical Guidelines in Paediatric Dentistry: diagnosis, prevention and management of dental erosion. Int $\mathrm{J}$ Paediatr Dent 2008; 18:29-38.

44. Zebrauskas A, Birskute R, Maciulskiene V. Prevalence of dental erosion among the young regular swimmers in Kaunas, Lithuania. J Oral Maxillofac Res 2014;5:6.

45. West NX, Hughes JA, Addy M. Erosion of dentine and enamel in vitro by dietary acids: the effect of temperature, acid character, concentration and exposure time. J Oral Rehabil 2000;27:875-880.

46. Carvalho TS, Colon P, Ganss C, Huysmans MC, Lussi A, et al. Consensus report of the European Federation of Conservative Dentistry: Erosive tooth wear-diagnosis and management. Clin Oral Investig 2015;19:1557-1561.

47. Hara AT, Zero DT. The potential of saliva in protecting against dental erosion. Monogr Oral Sci 2014;25:197205.

48. Hannig M, Balz M. Protective properties of salivary pellicles from two different intraoral sites on enamel erosion. Caries Res 2001;35:142-148.

49. Hannig M, Fiebiger $M$, Güntzer $M$, Döbert $A$, Zimehl $\mathrm{R}$, et al. Protective effect of the in situ formed short-term salivary pellicle. Arch Oral Biol 2004;49:903-910.

50. Featherstone J, Lussi A. Understanding the chemistry of dental erosion. Monogr Oral Sci 2006;20:66-76.

51. Honório HM, Rios $D$, Júnior ESP, de Oliveira DSB, Fior FA, et al. Effect of acidic challenge preceded by food consumption on enamel erosion. Eur J Dent 2010;4:412-417. 52. Hattab FN, Yassin OM. Etiology and diagnosis of tooth wear: A literature review and presentation of selected cases. Int J Prosthodont 2000;13:101-107. 
53. Mehta SB, Banerji S, Millar BJ, Suarez-Feito JM. Current concepts on the management of tooth wear: Part 1. Assessment, treatment planning and strategies for the prevention and the passive management of tooth wear. Br Dent J 2012;212:17-27.

54. Krishna MG, Rao KS, Goyal K. Prosthodontic management of severely worn dentition: including review of literature related to physiology and pathology of increased vertical dimension of occlusion. J Indian Prosthodont Soc 2005;5:89-93.

55. Johansson AK, Lingström $P$, Imfeld $T$, Birkhed D. Influence of drinking method on tooth-surface $\mathrm{pH}$ in relation to dental erosion. Eur J Oral Sci 2004;112:484-489.

56. The Glossary of Prosthodontic Terms: 9th Edition. J Prosthet Dent 2017;117:1-105.

57. Ghai, Singh K, Renuka, Gupta, Gaurav. The management of worn dentition-A systematic approach. Indian J Dent Sci 2013;5:136-141.

58. Lee $H E$, Lin $C L$, Wang $C H$, Cheng $C H$, Chang $\mathrm{CH}$. Stresses at the cervical lesion of maxillary premolar-A finite element investigation. J Dent 2002;30:283-290.

59. Grippo JO, Simring M, Coleman TA. Abfraction, abrasion, biocorrosion, and the enigma of noncarious cervical lesions: A 20-year perspective. J Esthet Restor Dent 2012;24:10-23.

60. Varma S, Preiskel A, Bartlett D. The management of tooth wear with crowns and indirect restorations. $\mathrm{Br}$ Dent J 2018;224:343-347.

61. Rees JS, Hammadeh M, Jagger DC. Abfraction lesion formation in maxillary incisors, canines and premolars: A finite element study. Eur J Oral Sci 2003;111:149-154.

62. Shellis RP, Addy M. The interactions between attrition, abrasion and erosion in tooth wear. Monogr Oral Sci 2014; 25:32-45.

63. Harpenau LA, Noble WH, Kao RT. Diagnosis and management of dental wear. J Calif Dent Assoc 2011;39:225231.

64. López-Frías FJ, Castellanos-Cosano L, MartánGonzález J, Llamas-Carreras JM, Segura-Egea JJ. Clinical measurement of tooth wear: Tooth wear indices. J Clin Exp Dent 2012;4:48-53.

65. Loomans B, Opdam N, Sterenborg B, Attin T, Bartlett $D$, et al. Severe tooth wear: European consensus statement on management guidelines. J Adhes Dent 2017;19:111-119.

66. McCay CM, Restarski JS, Bieri JG, Gobtner Jr. RA. Effects of acid beverages containing fluoride on the teeth and bones of dogs. Fed Proc 1946;5:147.

67. Eccles JD. The treatment of dental erosion. J Dent 1978;6:217-221.

68. Eccles JD. Dental erosion of nonindustrial origin. A clinical survey and classification. J Prosthet Dent 1979;42:649-653.
69. Bardsley PF, Taylor S, Milosevic A. Epidemiological studies of tooth wear and dental erosion in 14-year-old children in North West England. Part 1: The relationship with water fluoridation and social deprivation. Br Dent $\mathrm{J}$ 2004; 197:413-416.

70. Marro F, De Lat L, Martens L, Jacquet W, Bottenberg $\mathrm{P}$. Monitoring the progression of erosive tooth wear (ETW) using BEWE index in casts and their 3D images: A retrospective longitudinal study. J Dent 2018;73:70-75.

71. Kumar S, Keeling A, Osnes C, Bartlett D, O'Toole S. The sensitivity of digital intraoral scanners at measuring early erosive wear. J Dent. 2019;81:39-42.

72. Valati F. Classification and treatment of the anterior maxillary dentition affected by dental erosion: the ACE classification. Int $\mathrm{J}$ Periodontics Restorative Dent 2010;30:559-571.

73. Gandara BK, Truelove EL. Diagnosis and management of dental erosion. J Contemp Dent Pract 1999;1:1623.

74. Lobbezoo F, Naeije M. Bruxism is mainly regulated centrally, not peripherally. J Oral Rehabil 2001;28:10851091.

75. Mulic A, Tveit AB, Wang NJ, Hove LH, Espelid I et al. Reliability of two clinical scoring systems for dental erosive wear. Caries Res 2010;44:294-299.

76. Ganss C, Lussi A. Diagnosis of erosive tooth wear. Monogr Oral Sci 2014;25:22-31. 